\title{
Editorial
}

Apresentação do dossiê:

\section{Ciência, política e direitos humanos: diálogos sobre dignidade humana em tempo de pandemia}

A pandemia da Covid 19 nos impõe pensar o individual e o universal de forma entrelaçada. A luta pela vida pessoal passa a depender do cuidado do outro com sua própria vida e depender ainda de cientistas e políticos, que decidem pela sobrevivência da humanidade.

Pensar a ciência e a política como instrumento de defesa, não apenas da vida humana, mas da vida humana digna para todos foi o propósito desse dossiê que esta edição da RIDH oferece a seus leitores.

Mas afinal, o que vem ser a dignidade humana? Seria aquele o valor incomparável que cada ser humano possui pela própria condição intrínseca e a priori de pertencer à espécie humana; ou seja, por ser dotado da capacidade de consciência? Ou, a ideia de dignidade humana seria uma construção moral e histórica, diversa no tempo e no espaço, como é também a própria cultura de respeito à vida humana? Diante da primeira possibilidade - visão metafísica - nos resta, nesse tempo de pandemia, tentar resgatar o valor da vida humana, muitas vezes esquecido, e praticar a solidariedade emergencial para com aqueles que estão excluídos de uma vida digna. Entretanto, se tomarmos o outro caminho, a visão histórico-cultural, o momento exige uma reflexão crítica e uma posicionamento diante do processo histórico, que estamos realizando enquanto humanidade.

Nessa compreensão, o respeito à dignidade humana é um esforço cognitivo e moral de superar nossa condição animal originariamente sob a lei da sobrevivência individual e da espécie, pela seleção natural. Ao longo dos séculos o ser humano vem criando os valores que traduzem seu entendimento do que seja o bem viver coletivo, ou seja, uma vida digna 
para todos: bem estar material sustentável, relações de solidariedade, respeito à diversidade etc. Todavia, sabemos que essa construção histórica, além de não ter consenso universal, traz contradições sociais profundas e não apenas problemas de relações interpessoais. Falamos em igualdade, liberdade e fraternidade desde o século XVIII, mas a civilização moderna construiu estruturas socioeconômicas que geram dominação, desigualdades e exclusão. A Covid 19 escancarou-nos mais uma vez essa realidade.

E a ciência de matriz ocidental moderna, que hoje nos possibilita a continuidade da vida com a tão esperada vacina, serviu de discurso - assim como a religião e a filosofia - para justificar a violência, a dominação e a exclusão nos povos colonizados, como nos apresenta Immanuel Wallerstein em $O$ universalismo europeu: a retórica do poder. O próprio discurso direitos humanos - o que de melhor produziu-se na ética ocidental - também ideologizou a expansão econômica, política e cultural da Europa ocidental e, hoje, dos EUA sobre os quatro cantos do mundo, quase sempre pelo poderio militar.

Não se trata aqui, é óbvio, de defender a atitude negacionista diante da ciência em nome de valores pré-modernos, sempre retomados na modernidade em períodos de retrocesso político, de conservadorismo moral e de autoritarismo travestido de democracia. Também não estamos falando daqueles conhecimentos mágicos de assimilação fácil e acelerada, com roupagem científica, apenas produzidos para o consumo de multidões seja política ou economicamente. Eles não são anunciadores de novos caminhos de conhecimento, como os alquimistas, mas propagandistas de crenças antigas com novas tintas.

A ciência de que está se falando neste dossiê, em diálogo com a política e os direitos humanos, é a ciência construída historicamente na modernidade ocidental. É a ciência que tem em seu DNA, por um lado, o racionalismo cartesiano gerador de um universalismo abstrato, e por outro, o empirismo baconiano, cujo método epistemológico busca propiciar ao ser humano poder sobre a natureza. Já em Novum Organum de Francis Bacon estão as características e finalidades do novo saber: conhecer é poder; conhecer é dominar; dominar é prever para controlar, explorar e (sabemos agora) acumular riquezas. Por outro lado esta mesma ciência já continha a gestação de um projeto ético concreto: minorar o sofrimento humano nesta vida, próprio de sua efemeridade, dando-lhe melhores condições de saúde, alimentação, moradia, conforto, etc.

Todavia vemos hoje que essa promessa de "felicidade" da ciência moderna está disponível apenas para um terço da humanidade. Hoje temos clara consciência que a miséria, a fome e grande parte das doenças 
não são de ordem natural; é um sofrimento injusto por ser consequência da dominação e exploração do outro, do preconceito e da exclusão. Sabemos que a ciência moderna contém uma contradição epistemológica interna por ser parte do projeto de universalização impositiva da cultura moderna ocidental. Nele, conhecer é poder dominar a natureza; e dominar a natureza e dominar o outro é um mesmo processo.

O saber científico construído na modernidade ocidental, sem dúvida é uma grande conquista da humanidade. Todavia, para se perpetuar num mundo - sem espaço epistemológico que justifique o antropocentrismo, o patriarcalismo, o racismo e o extrativismo - a ciência moderna deve dialogar com as epistemologias do Sul, na expressão de Boaventura, e colocar-se realmente a serviço de toda a humanidade. Este é um dos grandes desafios das universidades no século XXI, na construção de um novo paradigma de sociedade.

Portanto, o dossiê, que a RIDH apresenta, leva - muito mais do que as contradições históricas da ciência moderna de reconhecimento e de dominação do outro - a esperança de que essa contradição possa ser superada, com o fim desse modelo socioeconômico de civilização em que vivemos.

Em outras palavras, reconhecendo tais estruturas históricas do pensamento científico de matriz ocidental, o presente dossiê propõe trazer reflexões a partir do olhar de várias ciências - em diálogo com a política e aos direitos humanos - que possam contribuir na promoção da cultura de respeito à dignidade humana neste tempo de pandemia.

Com este objetivo, a RIDH no 15 acolheu artigos de pesquisadores de diversas áreas da ciência como: filosofia, psicologia, educação, antropologia, ciência linguística, ciências da natureza, matemática, geografia e história. As reflexões sobre a dignidade humana, tanto em situações de negação, quanto em contextos de lutas e conquistas perpassaram transversalmente questões suscitadas pelo tempo de pandemia: - o papel dos intelectuais na crise da modernidade; - a mercantilização da vida, - a dignidade humana como condição compartilhada; - diálogo entre a ciência e a ética; - ensino humanizado das ciências da natureza; - o compromisso ético-politico na formação do psicólogo; - a dimensão subjetiva e reflexões em tempos de pandemia; - marcas da Covid 19 na subjetividade; - desigualdade, conectividade e o direito à educação; - educação sobre dignidade e direitos humanos; - crise sanitária e humanitária nos povos indígenas; - a ciência linguística na construção da dignidade humana; - a educação matemática crítica e o respeito à dignidade humana; - a geografia crítica e as questões de direitos humanos; e - o sujeito histórico como condição da 
dignidade humana.

Assim, deixa-se registrado nessa produção acadêmica, não apenas o luto por tantas ausências e sofrimentos nesse tempo de pandemia, como também a luta pela dignidade humana num outro mundo possível.

Boa leitura!

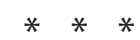

Os posicionamentos, contidos nos artigos publicados, são de responsabilidade dos/as autores/as.

Dezembro de 2020.

Clodoaldo Meneguello Cardoso

Editor da RIDH-Unesp 